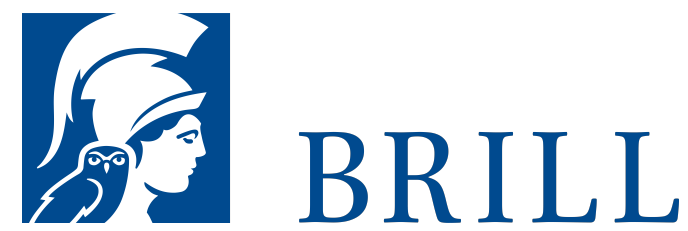

\title{
Out of Otherness
}

Characters and Narrators in the Dutch Venereal Disease Debates 1850-1990

\section{Author: Annet Mooij}

From a punishment for the immoral acts of others, venereal disease has become a malady that may confront any one of us. This book examines the different stages in this long development and reveals the strange disjunction between waves of public anxiety and the factual incidence of disease, in this troubled overlap between medical science and social life. It describes the various efforts that have been made since 1850 to contain the hazard of sexually transmitted diseases and places the changing views on venereal infection in their historical and social context. The comparisons drawn between the late 19thcentury battle against syphilis and present-day responses to the AIDS epidemic underscore the notable changes that have taken place not only in thinking about sexuality, but also in the authority of the medical profession and in the position of patients vis-à-vis policy-makers and all those involved in determining modes of treatment and prevention.

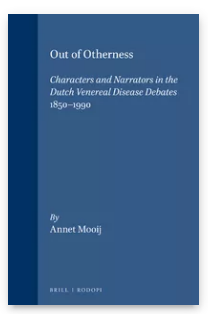

Pages: $250 \mathrm{pp}$.

Language:

English

Subjects:

History of

Medicine,

History, General,

Social Sciences

Publisher: Brill

Series:

Clio Medica

Online, Volume:

47

Clio Medica,

Volume: 47

E-Book (PDF)

Released online:

10 Feb 2020

ISBN: 978-90-

04-41856-1

List price

USD $\$ 164.00$

Hardback

Publication date:

o1 Jan 1998

ISBN: 978-90-

420-0267-8

List price

USD $\$ 155.00$

Paperback

Publication date:

o1 Jan 1998 
For more information see brill.com

ISBN: $978-90-$

420-0257-9

Order information: Order online at brill.com +44 330333 o049 | customerservices@brill.com Submission information: brill.com/authors

Titles published by Brill | Fink, Brill | mentis or Brill | Schöningh: +49(o)71 5413279216 | brill@brocom.de 